\title{
HAZARDOUS PROPERTIES OF BROMINATED, PHOSPHORUS, CHLORINATED, NITROGEN AND MINERAL FLAME RETARDANTS IN PLASTICS WHICH MAY HINDER THEIR RECYCLING
}

\section{Pierre Hennebert *}

Ineris (French National Institute for Industrial Environment and Risks), CS 10440, F-13592 Aix-en-Provence Cedex 03, France

Article Info:
Received:
17 August 2021
Revised:
3 November 2021
Accepted:
24 November 2021
Available online:
16 December 2021
Keywords:
ECHA
Hazard
Persistent organic pollutant (POP)
Persistent bioaccumulative and
toxic (PBT)
Endocrine disruptor (ED)

\section{INTRODUCTION}

The flame retardants (FR) protect people and property from fire, by their retarding or intumescent properties. They are useful additives in plastics of electrical circuits, furniture, upholstery, thermal insulation of electrical and electronic equipment, vehicles, construction products, textile and non-food packaging (Drage et al. 2018, review in Hennebert 2020). Their use is generalised (Alaee et al. 2003) and they are present in household products (Chen S.J. et al. 2010). The toxic ones are subject of active research for their substitution, as halogen-free combination of phosphorus and silicon (Cui et al. 2021, Gibertini et al. 2021), use of alumina in battery (Delaporte et al. 2021), development of eco-friendly NP substances (Liao et al. 2021) or polyols substances (Chen M-J et al 2018), or more physical approach for polyester (Zhang et al. 2021) or polypropylene (Zhao et al. 2021). The use of plastics in Europe in the sectors using FR is important: $19.8 \%$ for building and construction, $16.7 \%$ for medical equipment, plastic furniture and furniture equipment, technical parts used for mechanical engineering or machine-building, and $4.1 \%$ for household, leisure and sport (PlasticsEurope 2018), totalling so about $40 \%$ of the plastics used in EU or $20 \mathrm{Mt}$ per year, as much as packaging (food and non-food) plastics (calculated from PlasticsEurope 2018).

Some plastic additives are banned over time by the Persistent Organic Pollutants (POPs) recommendations of the United Nations Stockholm Convention or other regulations (EU 2016, 2019). Prohibited substances are gradually replaced by other substances (Santillo and Johnston 2003, AFP 2015). What are the substitutes or the used substances and their eventual hazard properties? Are they used in concentration(s) that make(s) the plastic hazardous when it becomes a waste?

To set a list of flame retardants, three sources of information were used: (i) the Plastic Additives Initiative (PAI), a collaboration between the ECHA and the plastics industries, which in 2019 delivered a list of 418 additives currently used in products in the EU (it is not known if it is EU26 or EU27), along with their function(s), the polymer(s) they improve, and their functional concentration(s) (ECHA 2021a); (ii) the catalogs of three large producers of brominated flame retardants (Hennebert, 2021), and (iii) the 
catalog of the Phosphorus, Inorganic and Nitrogen Flame Retardants Association (PINFA) site (PINFA 2021b).

The additives are first detailed by function, by polymer and by functional concentration mentioned in the PAI file. Their hazardous properties of human toxicity and ecotoxicity from the ECHA registration site of chemicals in the EU (ECHA 2021b, open access chemical portal https://echa. europa.eu/information-on-chemicals) are then presented by families based on main elements (bromine, phosphorus and phosphorus-chlorine, chlorine, nitrogen, antimony, boron and boron-zinc, magnesium, aluminium). When their functional concentration is documented, it is compared for every hazard statement with the concentration that makes a waste hazardous (EU 2014, 2017). A synthesis of the chemical classification of all the flame retardants of plastics officially used in the EU is presented.

The sorting and management options of these flame-retarded plastics are then discussed.

\section{MATERIAL AND METHODS}

\subsection{The list of flame retardants used in the EU}

A common list of used additives in plastics is available on the so-named "Mapping exercise - Plastic additives initiative" (https://echa.europa.eu/fr/plastic-additives-initiative ). This joint project by the ECHA and plastics industries since 2016 resulted in a list of 418 functional additives used in plastics, including information on the polymers they are most found in and the typical concentration ranges. The mapping considered substances registered under REACH at above 100 tonnes per year, and focused on plasticisers, flame retardants, pigments, antioxidants, antistatic agents, nucleating agents and various types of stabilisers. An excel file has been delivered in 2019. The polymers' names are abbreviated: ABS: acrylonitrile butadiene styrene; PA: polyamide ; PC: polycarbonate ; PET: polyethylene terephthalate; PMMA: polymethyl methacrylate; Polyolefin-I: polyethylene group; Polyolefin-II: polypropyl- ene; EPS: (expanded) polystyrene; PUR: polyurethane; PVC (rigid): polyvinylchloride (without plasticisers); PVC (soft): polyvinylchloride (with plasticisers).

The catalogs of the three large brominated flame retardants producers (Albemarle, ICL, Lanxess) were compiled and the 34 substances (some polymers that do not have to be registered, some are not for sale in EU) are presented in details in Hennebert (2021). The significant production in China ( $>50 \%$ of all BFRs) has not been documented.

The Phosphorus, Inorganic and Nitrogen Flame Retardants Association (PINFA 2021a) presents a summary of its stakeholders flame retardants (PINFA 2021b), which has been used here.

\subsection{Properties of substances and hazard classifica- tion of waste}

The self-reported chemical properties of substances on human health and the environment are found in their European ECHA registration dossier (https://echa.europa.eu/ information-on-chemicals). The "Brief Profiles" are a practical summary of the dossier. The most frequently reported hazard statement codes have been used here. Some hazards are graduated from level 1 (high) to level 4 (low). For some substances, the ECHA mentions its own classification, or indicates that a re-assessment is in progress.

The hazard classification of the additivated plastics as waste is done according to the EU regulations (EU 2014, EU 2018). A synthesis is presented in Hennebert (2019a). In the tables, the concentration of hazard statements classifying a waste as hazardous is indicated if it is $\leq 20 \%$.

\section{RESULTS AND DISCUSSION}

\subsection{Additives per function category and per polymer type}

The number of additives per function is presented in Figure 1 in decreasing order: Pigment agents (979 occur-

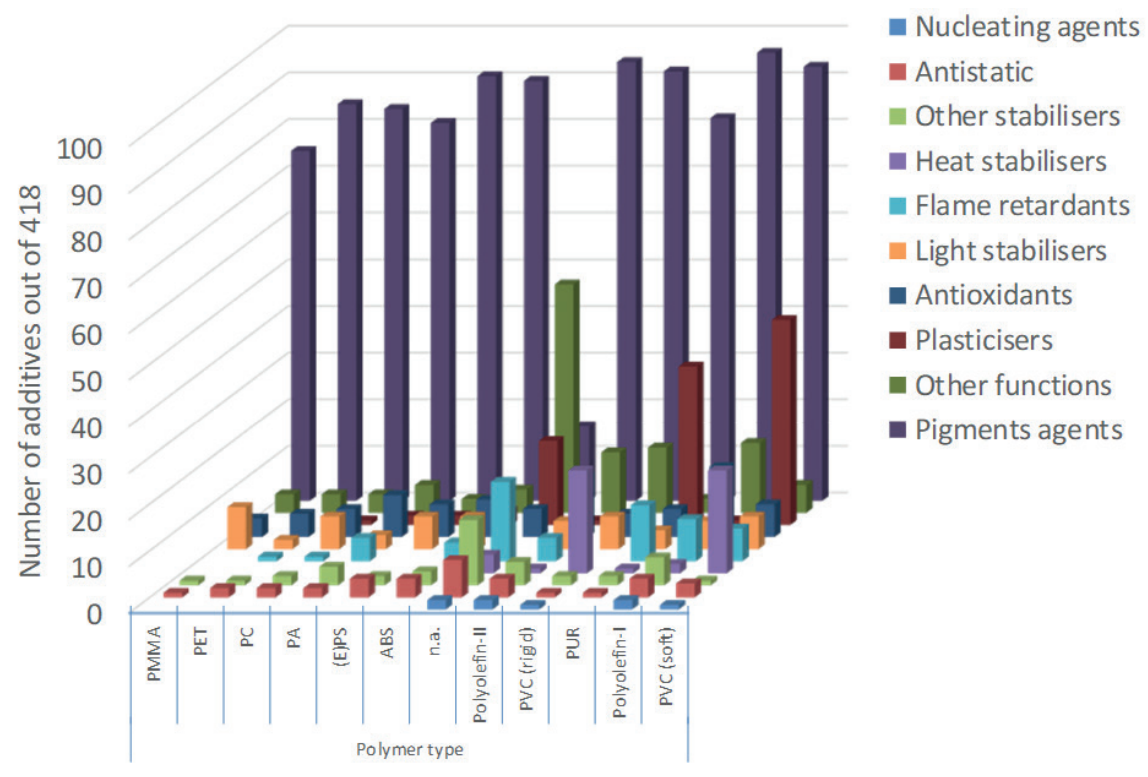

FIGURE 1: The number of additives in the Plastic Additives Initiative per function category and per polymer type. 


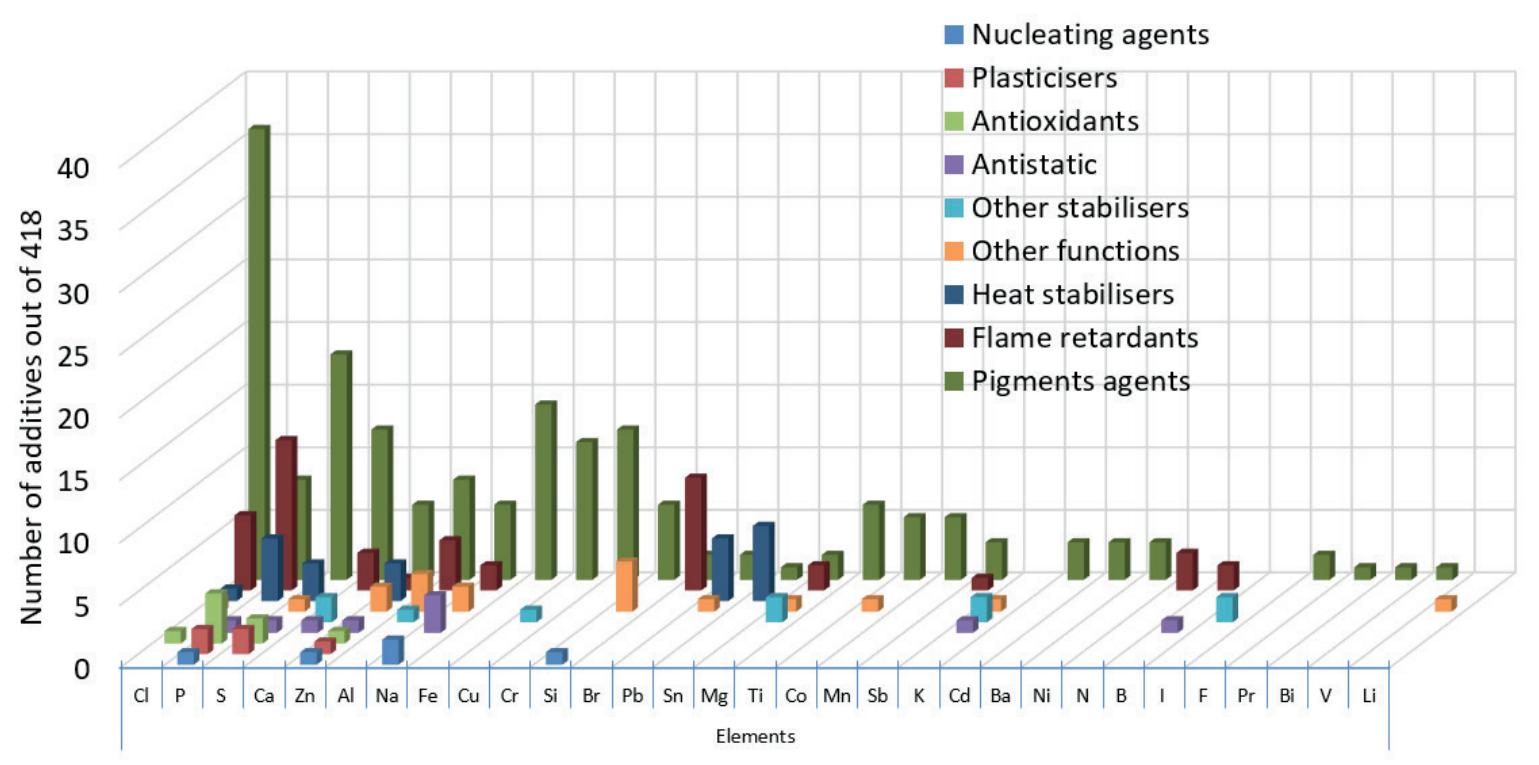

FIGURE 2: The number of additives in the Plastic Additives Initiative per function category and per element.

rences) $>$ Other functions $(126)>$ Plasticisers $(106)>$ Antioxidants $(91)>$ Light stabilisers $(65)>$ Flame retardants (61) > Heat stabilisers (52) > Other stabilisers (43) > Antistatic (36) > Nucleating agents (8). A total of 1567 occurrences for 418 substances, indicating that a substance may have more than one function.

\subsection{Additives per function category and per element}

The decreasing number of elements in additives is presented in Figure 2: $\mathrm{Cl}(45)>\mathrm{P}(33)>\mathrm{S}(27)>\mathrm{Ca}(18)>\mathrm{Al}, \mathrm{Zn}$ (16) $>\mathrm{Na}(15)>\mathrm{Fe}(14)>\mathrm{Cr}, \mathrm{Cu}(12)>\mathrm{Br}, \mathrm{Si}(11), \mathrm{Pb}(8)>\mathrm{Mg}$, $\mathrm{Sn}(7)>\mathrm{Co}, \mathrm{Ti}(6)>\mathrm{Mn}(5)>\mathrm{K}, \mathrm{Sb}(4)>\mathrm{B}, \mathrm{Ba}, \mathrm{Cd}, \mathrm{N}, \mathrm{Ni}(3)>$ $\mathrm{F}, \mathrm{I}(2)>\mathrm{Bi}, \mathrm{Li}, \mathrm{Pr}, \mathrm{V}(1)$. Total 300 . The elements $\mathrm{C}, \mathrm{O}$ and $\mathrm{H}$ are not accounted for, as well as $\mathrm{N}$ when it is in substitut- ing groups and is not the skeleton of the substances. Some additives have two elements, for instance the 3 additives (P- and $\mathrm{Cl}-$ ).

\subsection{Additives per functional concentration}

The concentration of additives recommended in the mixtures before moulding or injection of parts or plastic material is given for a part in the listing of the PAI. The available concentrations are summarized in Table 1 and Figure 3. The substances with the highest concentrations are shown in the last row of the table. Plasticisers and flame retardants are used at higher average concentrations than other additives. The three flame retardants that are

TABLE 1: The functional concentrations of additives by function category, with the additives with highest concentrations (sorted by decreasing mean concentration - yellow row) (in case of range, the highest concentration is used).

\begin{tabular}{|c|c|c|c|c|c|c|c|c|c|c|c|}
\hline $\begin{array}{l}\text { Functional } \\
\text { concentra- } \\
\text { tion (\%) }\end{array}$ & $\begin{array}{l}\text { Plasticis- } \\
\text { ers }\end{array}$ & $\begin{array}{l}\text { Flame } \\
\text { retardants }\end{array}$ & Antistatic & $\begin{array}{l}\text { Pigments } \\
\text { agents }\end{array}$ & $\begin{array}{c}\text { Other } \\
\text { functions }\end{array}$ & $\begin{array}{c}\text { Heat } \\
\text { stabilisers }\end{array}$ & $\begin{array}{l}\text { Light } \\
\text { stabilisers }\end{array}$ & $\begin{array}{c}\text { Other } \\
\text { stabilisers }\end{array}$ & $\begin{array}{l}\text { Antioxi- } \\
\text { dants }\end{array}$ & $\begin{array}{l}\text { Nucleating } \\
\text { agents }\end{array}$ & Total \\
\hline $\mathrm{N}$ data & 40 & 19 & 4 & 102 & 16 & 23 & 13 & 7 & 17 & 2 & 243 \\
\hline $\begin{array}{l}\text { (including } \\
\text { concen- } \\
\text { tration } \\
\text { ranges) }\end{array}$ & 33 & 7 & & 5 & 4 & & 8 & 2 & 12 & & 71 \\
\hline Min & 0.5 & 0.3 & 1.0 & 0.1 & 0.1 & 1.5 & 0.0 & 0.2 & 0.0 & 0.2 & 0.0 \\
\hline Mean & 20.4 & 13.7 & 5.3 & 3.4 & 2.3 & 2.2 & 1.4 & 0.7 & 0.7 & 0.2 & 6.4 \\
\hline Max & 35.0 & 50.0 & 10.0 & 50.0 & 20.0 & 4.0 & 6.0 & 1.0 & 3.0 & 0.2 & 50.0 \\
\hline $\begin{array}{l}\text { Sub- } \\
\text { stances } \\
\text { with high } \\
\text { concentra- } \\
\text { tions (\%) }\end{array}$ & $\begin{array}{c}\text { Dodeca- } \\
\text { noic acid, } \\
\text { subtituted } \\
\text { phtalates } \\
\text { and other } \\
\text { organics } \\
\text { (33 sub- } \\
\text { stances } \\
\text { used at } \\
35 \%)\end{array}$ & $\begin{array}{c}\text { Aluminium } \\
\text { hydroxide } \\
(50 \%) ; \\
\text { 1,1'-(eth- } \\
\text { ane-1,2-di- } \\
\text { yl) } \\
\text { bis[penta- } \\
\text { bromo- } \\
\text { benzene] } \\
(35 \%) ; \\
\text { Phenol, } \\
\text { isopro- } \\
\text { pylated, } \\
\text { phosphate } \\
\text { (3:1) (35\%) }\end{array}$ & $\begin{array}{c}\text { Multi- } \\
\text { Walled } \\
\text { Carbon } \\
\text { Nanotubes } \\
\text { (MWCNT) } \\
(10 \%)\end{array}$ & $\begin{array}{c}\text { Barium } \\
\text { sulfate } \\
(50 \%) ; \text { Car- } \\
\text { bon black } \\
(40 \%)\end{array}$ & $\begin{array}{l}\text { Kaolin } \\
(20 \%- \\
\text { filler })\end{array}$ & $\begin{array}{c}\text { 2-ethyl- } \\
\text { hexyl } \\
\text { 10-eth- } \\
\text { yl-4,4- } \\
\text { dimethyl-7- } \\
\text { oxo-8- } \\
\text { oxa-3,5- } \\
\text { dithia-4- } \\
\text { stanna- } \\
\text { tetrade- } \\
\text { canoate } \\
(4 \%)\end{array}$ & $\begin{array}{c}2,2 '- \\
\text { methylen- } \\
\text { ebis } \\
\text { (6-(2H-ben- } \\
\text { zotri- } \\
\text { azol-2-yl) } \\
-4-(1,1,3,3- \\
\text { tetrameth- } \\
\text { ylbutyl) } \\
\text { phenol) } \\
(6 \%)\end{array}$ & $\begin{array}{l}\text { Calcium } \\
\text { oxide }(1 \%) \\
\text { Mag- } \\
\text { nesium } \\
\text { carbonate } \\
(1 \%)\end{array}$ & $\begin{array}{l}\text { Ethylenebi- } \\
\text { s(oxyeth- } \\
\text { ylene) } \\
\text { bis[3-(5- } \\
\text { tert-butyl- } \\
\text { 4-hydroxy- } \\
\text { m-tolyl) } \\
\text { propio- } \\
\text { nate] (3\%); } \\
2 \text { others } \\
\text { (3\%) }\end{array}$ & $\begin{array}{c}\text { 2,2'-meth- } \\
\text { ylene bis- } \\
\text { (4,6-di-tert. } \\
\text { butyl- } \\
\text { phenyl) } \\
\text { sodium } \\
\text { phosphate } \\
(0.2 \%) ; \\
\text { Sodium } \\
\text { benzoate } \\
(0.2 \%)\end{array}$ & \\
\hline
\end{tabular}




\section{Concentration of plastics additives ( $n=243)$}

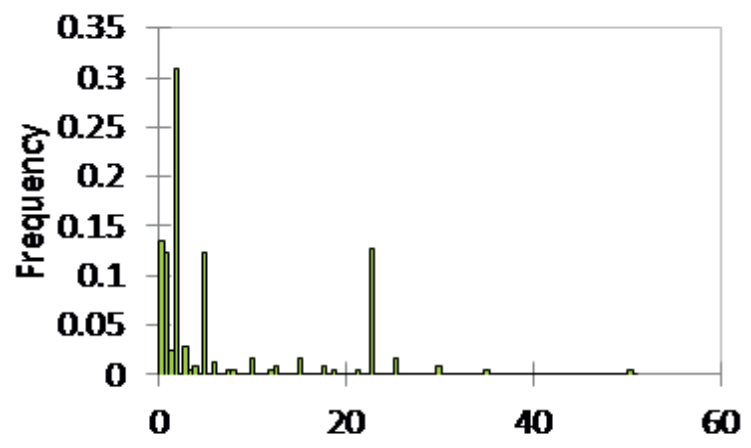

Functional Concentration (\%)

FIGURE 3: The functional concentrations of some additives in the Plastic Additives Initiative (when a range is documented, the mean concentration is presented).

used in the highest concentration are bromine, phosphorus and aluminum groups.

\subsection{Organo-brominated flame retardants}

Nine Brominated flame retardants (among a total of 35 FR in that list) are declared in the list of 418 plastic additives actually used in the EU (Table 2). Their situation is worrying. There are 2 substances classified as Persistent Organic Pollutants (POPs) and banned, and the 7 others are currently under re-assessment by the $\mathrm{ECHA}$ as persistent, bioaccumulative and toxic (PBT), endocrine disruptor (ED) or both.
A detailed table with additional brominated flame retardants from three large producer's catalogs can be found in (Hennebert 2021). In that list of 34 substances, some are not sold in the EU, and others are polymers, that have not been declared in the REACh system of ECHA. In total, there are 34 substances, among which 3 with functional concentrations making the additivated plastic hazardous, and 5 under re-assessment. Of these 5, 4 are listed in the PAI and are presented in Table 2, and the fifth one is 2,4,6-tribromophenol (CAS 118-79-6) and is reassessed in the PBT list. These substances are considered in the synthesis Table 7.

\subsection{Phosphorus and phosphorus-chlorine flame re- tardants}

Twelve substances are listed in the Plastic Additives Initiative, and 2 additional substances are found in the Phosphorus, Inorganic and Nitrogen Flame Retardants Association (PINFA) catalog, being in total 14 substances (Table 3 ). Four out of 14 substances have functional concentration greater than the concentration making plastic hazardous when it becomes a waste (EU waste classification). One substance is under assessment by the $\mathrm{ECHA}$.

\subsection{Organo-chlorinated flame retardants (without P)}

Three substances are listed in the Plastic Additives Initiative (Table 4). One out of 3 substances has a functional concentration greater than the concentration making plastic hazardous when it becomes a waste (EU waste classification) (according to reclassification by the ECHA of that substance). Two substances of 3 are under re-assessment by the ECHA.

TABLE 2: The chemical properties of the brominated flame retardants of the Plastic Additives Initiative (in red: the functional concentration is higher than the concentration that makes a waste hazardous; in yellow: re-assessment by the ECHA in progress).

\begin{tabular}{|c|c|c|c|c|c|c|c|c|c|}
\hline Name & Formula & CAS & $\mathrm{FC} \%$ & $\begin{array}{l}\text { Polymer } \\
\text { type }\end{array}$ & $\begin{array}{l}\text { Self-classi- } \\
\text { fication }\end{array}$ & & Note & ECHA & BP \\
\hline $\begin{array}{l}\text { Hexabromocyclododecane - } \\
\text { HBCD or HBCDD }\end{array}$ & $\mathrm{C}_{12} \mathrm{H}_{18} \mathrm{Br}_{6}$ & 25637-99-4 & n.a. & n.a. & & & $\mathrm{NU}$ & POP+others & + \\
\hline $\begin{array}{l}\text { Bis(pentabromophenyl) ether } \\
\text { - DecaBDE }\end{array}$ & $\mathrm{C}_{12} \mathrm{Br}_{10} \mathrm{O}$ & $1163-19-5$ & n.a. & n.a. & & & NU & POP+others & + \\
\hline $\begin{array}{l}\text { 2,4,6-tris(2,4,6-tribromophe- } \\
\text { noxy)-1,3,5-triazine }\end{array}$ & $\begin{array}{l}\mathrm{C}_{21} \mathrm{H}_{6} \mathrm{Br}- \\
{ }_{9} \mathrm{~N}_{3} \mathrm{O}_{3}\end{array}$ & $426-040-2^{*}$ & n.a. & n.a. & $\begin{array}{c}\text { Not } \\
\text { classified }\end{array}$ & & PAI+PC & PBT & + \\
\hline $\begin{array}{l}\text { 1,1'-(ethane-1,2-diyl)bis[penta- } \\
\text { bromobenzene] }\end{array}$ & $\mathrm{C}_{14} \mathrm{H}_{4} \mathrm{Br}_{10}$ & $84852-53-9$ & $15.0-35.0$ & $\begin{array}{l}\text { PUR; PVC } \\
\quad \text { (soft) }\end{array}$ & $\begin{array}{l}\text { Not } \\
\text { classified }\end{array}$ & & $\mathrm{PAl}+\mathrm{PC}$ & PBT & + \\
\hline $\begin{array}{l}\text { N,N'-ethylenebis(3,4,5,6-tetra- } \\
\text { bromophthalimide) }\end{array}$ & $\begin{array}{l}\mathrm{C}_{18} \mathrm{H}_{4} \mathrm{Br}- \\
{ }_{8} \mathrm{~N}_{2} \mathrm{O}_{4}\end{array}$ & $32588-76-4$ & n.a. & n.a. & $\begin{array}{l}\text { Not } \\
\text { classified }\end{array}$ & & PAI+PC & PBT & + \\
\hline $\begin{array}{l}\text { 1,1'-(isopropylidene)bis[3,5-di- } \\
\text { bromo-4-(2,3-dibromoprop- } \\
\text { oxy)benzene] }\end{array}$ & $\mathrm{C}_{21} \mathrm{H}_{20} \mathrm{Br}_{8} \mathrm{O}_{2}$ & $21850-44-2$ & 15 & n.a. & $\begin{array}{c}\text { Not } \\
\text { classified }\end{array}$ & & $\mathrm{PAI}+\mathrm{PC}$ & PBT, ED & + \\
\hline $\begin{array}{l}\text { 1,1'-(isopropylidene)bis[3,5-di- } \\
\text { bromo-4-(2,3-dibromo-2-meth- } \\
\text { ylpropoxy)benzene] }\end{array}$ & $\mathrm{C}_{23} \mathrm{H}_{24} \mathrm{Br}_{8} \mathrm{O}_{2}$ & 97416-84-7 & $\begin{array}{l}\text { n.a. } \\
\text { supposed } \\
15 \% \text { by } \\
\text { similarity }\end{array}$ & $\begin{array}{l}\text { PUR; PVC } \\
\quad \text { (soft) }\end{array}$ & $\begin{array}{c}\text { Not } \\
\text { classified }\end{array}$ & & PAI & ED & + \\
\hline $\begin{array}{l}\text { 2,2-bis(bromomethyl)pro- } \\
\text { pane-1,3-diol }\end{array}$ & $\mathrm{C}_{23} \mathrm{H}_{24} \mathrm{Br}_{8} \mathrm{O}_{2}$ & $3296-90-0$ & n.a. & n.a. & $\begin{array}{l}\text { Not } \\
\text { classified }\end{array}$ & & PAI & ED & + \\
\hline $\begin{array}{l}\text { 2,2',',6'-tetrabromo-',4'-isopro-' } \\
\text { pylidenediphenol }\end{array}$ & $\mathrm{C}_{15} \mathrm{H}_{12} \mathrm{Br}_{4} \mathrm{O}_{2}$ & 79-94-7 & $5.0-10.0$ & $\begin{array}{l}\text { Polyolefin-I; } \\
\text { Polyole- } \\
\text { fin-II; ABS }\end{array}$ & $\mathrm{H} 400$ & $\mathrm{H} 410$ 0.25\% & PAI & PBT, ED & + \\
\hline
\end{tabular}

n.a. = not available; $*$ = No CAS number in the file; NU: not used, banned; $P A l+P C=$ data from the Plastic Additives Initiative and in the Producer's catalogs; $P A I=$ data from the Plastic Additives Initiative; $P O P=$ persistent organic pollutant; $P B T=$ persistent, bioaccumulative and toxic $(P B T) ; E D=$ endocrine disruptor; $H 410=$ Ecotoxic chronic level 1. $B P=$ brief profile (summary report) in the ECHA 
TABLE 3: The chemical properties of the phosphorous and phosphorous-chlorine flame retardants of the Plastic Additives Initiative (in red: the functional concentration is higher than the concentration that makes a waste hazardous; in yellow: re-assessment by the ECHA in progress.

\begin{tabular}{|c|c|c|c|c|c|c|c|c|c|c|c|c|c|}
\hline Name & Formula & CAS & $\mathrm{FC} \%$ & Function & Polymer & $\begin{array}{l}\text { Self-classifi- } \\
\text { cation }\end{array}$ & & & & & & ECHA & BP \\
\hline $\begin{array}{l}\text { Reaction mass of } \\
\text { tris(2-chloropropyl) } \\
\text { phosphate and } \\
\text { tris(2-chloro-1-meth- } \\
\text { ylethyl) phosphate } \\
\text { and Phosphoric acid, } \\
\text { bis(2-chloro-1-methy- } \\
\text { lethyl) 2-chloropropyl } \\
\text { ester and Phosphoric } \\
\text { acid, 2-chloro-1-meth- } \\
\text { ylethyl bis(2-chloro- } \\
\text { propyl) ester }\end{array}$ & & $\begin{array}{c}\text { EC 911- } \\
815-4 \\
\text { No CAS } \\
\text { number }\end{array}$ & 15 & $\begin{array}{l}\text { Flame re- } \\
\text { tardants; } \\
\text { plasticiser }\end{array}$ & $\begin{array}{l}\text { PUR; PVC } \\
\text { (soft) }\end{array}$ & Not classified & & & & & & & + \\
\hline $\begin{array}{l}\text { Reaction mass of } \\
\text { p-t-butylphenyldiphe- } \\
\text { nyl phosphate and } \\
\text { bis(p-t-butylphenyl) } \\
\text { phenyl phosphate and } \\
\text { triphenyl phosphate }\end{array}$ & & $\begin{array}{l}\text { EC 700- } \\
990-0 \\
\text { No CAS } \\
\text { number }\end{array}$ & n.a. & $\begin{array}{l}\text { Flame } \\
\text { retardants }\end{array}$ & n.a. & $\mathrm{H} 400$ & $\begin{array}{l}\mathrm{H} 410 \\
0.25 \%\end{array}$ & $\begin{array}{l}\mathrm{H} 411 \\
2.5 \%\end{array}$ & & & & & + \\
\hline $\begin{array}{l}\text { Phenol, isopropylated, } \\
\text { phosphate (3:1) }\end{array}$ & $\mathrm{C}_{90} \mathrm{H}_{96} \mathrm{O}_{16} \mathrm{P}_{4}$ & $\begin{array}{l}68937- \\
41-7\end{array}$ & $\begin{array}{c}15.0- \\
35.0\end{array}$ & $\begin{array}{c}\text { Flame re- } \\
\text { tardants; } \\
\text { plasticiser }\end{array}$ & $\begin{array}{l}\text { PUR; PVC } \\
\text { (soft) }\end{array}$ & H361 3\% & $\begin{array}{c}\mathrm{H} 373 \\
10 \%\end{array}$ & H317 & $\begin{array}{l}\mathrm{H} 411 \\
2.5 \%\end{array}$ & $\begin{array}{l}\mathrm{H} 410 \\
0.25 \%\end{array}$ & $\mathrm{H} 413$ & PBT & + \\
\hline $\begin{array}{l}\text { Polyphosphoric acids, } \\
\text { ammonium salts }\end{array}$ & $\mathrm{H}_{48} \mathrm{~N}_{11} \mathrm{O}_{25} \mathrm{P}_{7}$ & $\begin{array}{l}68333- \\
79-9\end{array}$ & 30 & $\begin{array}{l}\text { Flame } \\
\text { retardants }\end{array}$ & $\begin{array}{l}\text { Polyole- } \\
\text { fin-I }\end{array}$ & Not classified & $\mathrm{H} 302$ & $\begin{array}{l}\mathrm{H} 319 \\
20 \%\end{array}$ & & & & & + \\
\hline $\begin{array}{l}\text { 1,3,5-triazine-2,4,6-tri- } \\
\text { amine phosphate }\end{array}$ & $\mathrm{C}_{3} \mathrm{H}_{9} \mathrm{~N}_{6} \mathrm{O}_{4} \mathrm{P}$ & $\begin{array}{l}41583- \\
09-9\end{array}$ & n.a. & $\begin{array}{l}\text { Flame } \\
\text { retardants }\end{array}$ & n.a. & Not classified & & & & & & & + \\
\hline $\begin{array}{l}\text { 2,2-bis(chlorometh- } \\
\text { yl)trimethylene } \\
\text { bis(bis(2-chloroethyl) } \\
\text { phosphate) }\end{array}$ & $\begin{array}{c}\mathrm{C}_{13} \mathrm{H}- \\
{ }_{24} \mathrm{Cl}_{6} \mathrm{O}_{8} \mathrm{P}_{2}\end{array}$ & $\begin{array}{l}38051- \\
10-4\end{array}$ & 12 & $\begin{array}{l}\text { Flame } \\
\text { retardants }\end{array}$ & PUR & Not classified & & & & & & & + \\
\hline $\begin{array}{l}\text { 6H-dibenz[c,e][1,2]oxa- } \\
\text { phosphorin 6-oxide }\end{array}$ & $\mathrm{C}_{12} \mathrm{H}_{9} \mathrm{O}_{2} \mathrm{P}$ & $\begin{array}{c}35948- \\
25-5\end{array}$ & n.a. & $\begin{array}{l}\text { Flame } \\
\text { retardants }\end{array}$ & n.a. & Not classified & H317 & & & & & Ss & + \\
\hline $\begin{array}{l}\text { Dimethyl propylphos- } \\
\text { phonate }\end{array}$ & $\mathrm{C}_{5} \mathrm{H}_{13} \mathrm{O}_{3} \mathrm{P}$ & $\begin{array}{c}18755- \\
43-6\end{array}$ & 15 & $\begin{array}{l}\text { Flame } \\
\text { retardants }\end{array}$ & PUR & H360 1B 0.3\% & $\begin{array}{c}\mathrm{H} 319 \\
20 \%\end{array}$ & & & & & & + \\
\hline $\begin{array}{l}\text { Tris[2-chloro-1- } \\
\text { (chloromethyl)ethyl] } \\
\text { phosphate }\end{array}$ & $\mathrm{C}_{9} \mathrm{H}_{15} \mathrm{Cl}_{6} \mathrm{O}_{4} \mathrm{P}$ & $\begin{array}{l}13674- \\
87-8\end{array}$ & n.a. & $\begin{array}{l}\text { Flame } \\
\text { retardants }\end{array}$ & n.a. & $\mathrm{H} 351: 1 \%$ & $\begin{array}{l}\mathrm{H} 410 \\
0.25 \%\end{array}$ & $\begin{array}{l}\mathrm{H} 411 \\
2.5 \%\end{array}$ & $\begin{array}{c}\mathrm{H} 315 \\
20 \%\end{array}$ & H302 & $\begin{array}{l}\text { H373 } \\
\text { H332 }\end{array}$ & $\begin{array}{c}\mathrm{H} 351 \\
1 \%\end{array}$ & + \\
\hline Calcium phosphinate & $\begin{array}{l}\mathrm{CaO}_{4} \mathrm{P}_{2}= \\
\mathrm{Ca}\left(\mathrm{PO}_{2}\right)_{2}\end{array}$ & $\begin{array}{l}7789- \\
79-9\end{array}$ & 1 & $\begin{array}{c}\text { Flame } \\
\text { retardants }\end{array}$ & $\begin{array}{l}\text { Polyole- } \\
\text { fin-I }\end{array}$ & $\mathrm{H} 2281$ & H302 & $\begin{array}{c}\mathrm{H} 228 \\
2\end{array}$ & $\begin{array}{c}\mathrm{H} 319 \\
20 \%\end{array}$ & $\begin{array}{l}\mathrm{H} 318 \\
10 \%\end{array}$ & & & + \\
\hline $\begin{array}{l}\text { Ammonium } \\
\text { dihydrogenorthophos- } \\
\text { phate }\end{array}$ & $\begin{array}{c}\mathrm{H}_{6} \mathrm{NO}_{4} \mathrm{P}= \\
\left(\mathrm{NH}_{4}\right) \mathrm{H}_{2} \mathrm{PO}_{4}\end{array}$ & $\begin{array}{c}7722- \\
76-1\end{array}$ & n.a. & $\begin{array}{l}\text { Flame } \\
\text { retardants }\end{array}$ & n.a. & Not classified & $\begin{array}{l}\mathrm{H} 319 \\
20 \%\end{array}$ & $\begin{array}{c}\mathrm{H} 315 \\
20 \%\end{array}$ & H335 & $\mathrm{H} 412$ & & & + \\
\hline Triethyl phosphate & $\begin{array}{l}\mathrm{C}_{6} \mathrm{H}_{15} \mathrm{O}_{4} \mathrm{P}= \\
\left(\mathrm{C}_{2} \mathrm{H}_{5}\right)_{3} \mathrm{PO}_{4} \\
\mathrm{P}_{2}\end{array}$ & $78-40-0$ & 10 & $\begin{array}{l}\text { Flame } \\
\text { retardants }\end{array}$ & PUR & H302 & $\begin{array}{c}\mathrm{H} 319 \\
20 \%\end{array}$ & H336 & & & & $\begin{array}{c}\mathrm{H} 302 \\
25 \%\end{array}$ & + \\
\hline $\begin{array}{l}\text { Fyroflex SOL-DP = Hy- } \\
\text { droquinone bis-phos- } \\
\text { phate (= benzene-1,4- } \\
\text { diol) (PINFA) }\end{array}$ & n.a. & $\begin{array}{l}\text { EC } 479- \\
310-7\end{array}$ & & $\begin{array}{l}\text { Flame } \\
\text { retardants }\end{array}$ & & Not classified & & & & & & & + \\
\hline $\begin{array}{l}\text { red phosphorus } \\
\text { (PINFA) }\end{array}$ & $P$ & $\begin{array}{c}\text { EC 918- } \\
594-3\end{array}$ & & $\begin{array}{l}\text { Flame } \\
\text { retardants }\end{array}$ & & $\begin{array}{l}\mathrm{H} 228 \text { flam- } \\
\text { mable solid }\end{array}$ & $\mathrm{H} 412$ & & & & & & + \\
\hline
\end{tabular}

PBT = persistent, bioaccumulative and toxic (PBT); Ss = skin sensitising; H302 Acute Toxic 4 (oral); H351 Carcinogenic 2; H360 1B Reprotoxic 1A and 1B; H361 Reprotoxic $2 ; H 410=$ Ecotoxic chronic $1 ; H 411=$ Ecotoxic chronic $2 . B P=$ brief profile (summary report) in the ECHA site

TABLE 4: The chemical properties of the chlorinated flame retardants of the Plastic Additives Initiative (in red: the functional concentration is higher than the concentration that makes a waste hazardous; in yellow: re-assessment by ECHA in progress).

\begin{tabular}{|c|c|c|c|c|c|c|c|c|}
\hline Name & Formula & CAS & FC\% & Function & Polymer & $\begin{array}{l}\text { Self-classifi- } \\
\text { cation }\end{array}$ & ECHA & BP \\
\hline $\begin{array}{l}\text { Alkanes, C14-17, } \\
\text { chloro }\end{array}$ & - & $85535-85-9$ & 15 & $\begin{array}{l}\text { Flame } \\
\text { retardants; } \\
\text { plasticiser }\end{array}$ & PUR; PVC (soft) & Not classified & $\begin{array}{c}\text { PBT H400 H410 } \\
0.25 \% \text { H362 } \\
\text { Assessment }\end{array}$ & + \\
\hline $\begin{array}{l}\text { Paraffin waxes } \\
\text { and Hydrocar- } \\
\text { bon waxes, } \\
\text { chloro }\end{array}$ & - & 63449-39-8 & & $\begin{array}{l}\text { Flame } \\
\text { retardants; } \\
\text { plasticiser }\end{array}$ & PUR; PVC (soft) & $\begin{array}{c}\text { Not classified, } \\
\text { H319, H400, } \\
\text { H362 }\end{array}$ & & + \\
\hline Dechlorane plus & $\mathrm{C}_{18} \mathrm{H}_{12} \mathrm{Cl}_{12}$ & $13560-89-9$ & 3 & $\begin{array}{l}\text { Flame retar- } \\
\text { dants }\end{array}$ & Polyolefin-I & Not classified & PBT, POP & + \\
\hline
\end{tabular}

$P B T=$ persistent, bioaccumulative and toxic; $P O P=$ persistent organic pollutant; $H 363=$ Reprotoxic $3 ; H 400=$ Ecotoxic acute $1 ; H 410=E$ cotoxic chronic 1 . $B P=$ brief profile (summary report) in the ECHA site 


\subsection{Nitrogenous flame retardants}

Many substances incorporate nitrogen. Here are only considered the substances where nitrogen is part of the molecular skeleton and has a large mass fraction (> 50\%) of the molecule.

Three substances are listed in the Plastic Additives Initiative, and 2 additional substances are found in the Phosphorus, Inorganic and Nitrogen Flame Retardants Association (PINFA) catalog, for a total of 5 substances (Table 5). Melam is a condensation product made of 2 molecules of melamine. On heating, melam first loses ammonia to form melem (with three triazine rings), and then melon (a condensation product of melem). Melon is finding only experimental use at this stage (PINFA 2021).

Two out of 5 substances have functional concentrations above the concentration making plastic hazardous when it becomes a waste (EU waste classification). One substance is under reassessment by the ECHA.

\subsection{Mineral flame retardants}

The carcinogenic antimony oxide is placed first (Table 6), followed by 9 flame retardants ordered by group of the periodic table of elements: boron group $(\mathrm{B}, \mathrm{Al})$ and alkaline earth metals $(\mathrm{Mg}, \mathrm{Ca})$.

Diantimony trioxide is used as a synergist of brominated flame retardants, with a functional concentration of $8 \%$. That substance is $\mathrm{H} 351$ Carcinogenic level 2 (low level), with a concentration limit of $1 \% \mathrm{Sb}_{2} \mathrm{O}_{3}(=0.83 \% \mathrm{Sb})$ in waste, which makes it hazardous. As the speciation of total Sb cannot be done routinely, and as it is a generic classification ("antimony compounds") (Hennebert 2019), a plastic with a total concentration of $0.83 \%$ of $\mathrm{Sb}$ is classified as hazardous.

Aluminum hydroxide can be used as flame retardant up to $50 \%$. This substance may classify a waste as HP 4 "Irritant" if its concentration is $\geq 20 \%$, due to its hazard statement H319 "Eye irritant 2" (low level). It is probably not irritating to the eyes when incorporated into a polymer, such as polypropylene for outdoor furniture. As in this case eye exposure is unlikely, the risk is low, and it is not considered here as triggering a classification of hazard in plastic waste.

\subsection{Synthesis of classification of flame retardants for hazardous concentrations and for re-asses- sment by the ECHA}

The number of FRs, the (minimum) number of FRs with a functional concentration greater than the hazardous concentration, and the number of FRs under reassessment by the ECHA are presented in Table 7. The total number of 69 FRs is consistent with the number 75 recently published (Haarman et al. 2020).

In the PAI alone, 35 flame retardants are used in the EU. Nine of them $(=26 \%)$ are used at concentrations greater than those making plastic waste with these additives hazardous (when this concentration is documented), and 12 of them $(=34 \%)$ are under re-assessment by the ECHA and may be restricted or prohibited in the future.

In the PAI and the manufacturer's catalogs, 69 flame retardants are used in the EU. Twelve of them $(=17 \%)$ are used at concentrations greater than those making plastic waste dangerous with these additives (when this concentration is documented): 4 bromines, 4 phosphorus, 1 chlorine, 2 nitrogen and 1 mineral (antimony trioxide). Of these 69 substances, 13 of them $(=19 \%)$ are under re-assessed by the ECHA and may be restricted or banned in the future.

\subsection{Management of these plastics}

These plastics should be separated from the plastic stream during recycling. The sorting can be done by product origin (if well characterised beforehand), by density (FR make plastics denser), or by the presence of substances or elements by optical methods. Density sorting is obtained by flotation in a bath or by X-ray transmission. Some plastics of specific items can be closed loop recycled if disassembled and processed separately (Tange et al. 2012).

For the sorting of a plastic fraction without FR, the additional density created by the FR unfortunately overlaps with the density ranges of some non-additivated polymers (soft PVC, PC+ABS, PC, some PP, some PS, Polybutylene terephthalate - PBT, hard PVC, PET according to Haarman et al. 2020). Today, this results in a loss of "pure" or potentially recyclable polymer when only density is used. This loss was estimated to be $30 \%$ in number of parts in one batch of WEEE plastics (Hennebert 2019b) (Figure 4). In this figure, the distribution of total bromine of 350 individual particles in the dense fraction $(>1.18 \mathrm{~kg} / \mathrm{l})$ of plastic scraps of screens, mainly cathode ray tubes (CRT), is presented. A first group $<1000 \mathrm{mg} / \mathrm{kg}$ of about $30 \%$ of particle numbers are the dense unbrominated plastics, or plastics with non-brominated additives. An intermediate group of 15000 - $45000 \mathrm{mg} \mathrm{Br} / \mathrm{kg}$ has insufficient concentration for fire protection, probably due to improper recycling of brominated plastics. A third group of $50000-150000 \mathrm{mg} \mathrm{Br} /$ $\mathrm{kg}$ is protected against fire by brominated flame retardants.

A second step pre- or post-density sorting could avoid the loss of dense polymers or polymers with additives other than unwanted in the dense fraction. This requires the identification or measurement of substances or elements. Today, two methods are available:

by X-Ray fluorescence (XRF) with a handheld device or sorting machine. The measurable elements of FR are $\mathrm{Mg}$, $\mathrm{Al}, \mathrm{P}, \mathrm{Cl}, \mathrm{Ca}, \mathrm{Br}, \mathrm{Sb}$. The elements $\mathrm{B}, \mathrm{N}$ and $\mathrm{F}$ are too light to be measured, but are present only in some FRs (Figure 2). Ratio of element concentrations can be calculated and improve the specificity of the measurement and the sorting;

by short-wave infrared hyperspectral imaging (1 000 $2500 \mathrm{~nm}$ ) calibrated for polymer type, $\mathrm{Br}$ and $\mathrm{Sb}$ recognition (Bonifazzi et al. 2021). The technology is ready in the laboratory stage but not suitable for black plastics, as they do not reflect infrared waves.

For the FR fraction, the simplest management of these plastics would be their reuse as flame retardant plastics. Due to the heterogeneous and variable composition, to date and to our knowledge, no article producer reuses these plastics, at least the brominated ones. One possible solution is chemical dissolution or decomposition, separation of additives and reconditioning of the purified polymer or building blocks for the chemical industry. For the specific case of hexabromocyclododecane in EPS insulation, this technology is currently in the pilot phase (PolystyreneLoop 
TABLE 5: The chemical properties of the nitrogenous flame retardants of the Plastic Additives Initiative and PINFA catalog (in red: the functional concentration is higher than the concentration that makes a waste hazardous).

\begin{tabular}{|c|c|c|c|c|c|c|c|c|c|c|c|c|}
\hline Name & Formula & CAS & FC\% & $\begin{array}{l}\text { Polymer } \\
\text { type }\end{array}$ & $\begin{array}{l}\text { Self-clas- } \\
\text { sification }\end{array}$ & & & & & & ECHA & BP \\
\hline $\begin{array}{l}\text { Melamine }=1,3,5 \text {-tri- } \\
\text { azine-2,4,6-triamine }\end{array}$ & $\mathrm{C}_{3} \mathrm{H}_{6} \mathrm{~N}_{6}$ & 108-78-1 & 25 & PUR & $\begin{array}{l}\text { Not classi- } \\
\quad \text { fied }\end{array}$ & H361 3\% & & & & & & + \\
\hline $\begin{array}{l}\text { Cyanuric acid = 1,3,5-tri- } \\
\text { azine-2,4,6-trio }\end{array}$ & $\mathrm{C}_{3} \mathrm{H}_{3} \mathrm{~N}_{3} \mathrm{O}_{3}$ & $108-80-5$ & n.a. & $\begin{array}{l}\text { Polyole- } \\
\text { fin-l; Poly- } \\
\text { olefin-II }\end{array}$ & H319 & $\begin{array}{l}\text { Not classi- } \\
\quad \text { fied }\end{array}$ & H335 & $\begin{array}{c}\mathrm{H} 315 \\
10 \%\end{array}$ & H302 & H332 & & + \\
\hline $\begin{array}{l}\text { 1,3,5-tri- } \\
\text { azine-2,4,6(1H,3H,5H)-tri- } \\
\text { one, compound with } \\
\text { 1,3,5-triazine-2,4,6-tri- } \\
\text { amine }(1: 1)\end{array}$ & $\mathrm{C}_{6} \mathrm{H}_{9} \mathrm{~N}_{9} \mathrm{O}_{3}$ & $\begin{array}{c}37640- \\
57-6\end{array}$ & $5.0-30.0$ & PUR; PA & H373 10\% & $\begin{array}{l}\text { Not classi- } \\
\quad \text { fied }\end{array}$ & & & & & & + \\
\hline $\begin{array}{l}\text { Melamine homologues } \\
\text { such as melam, melem } \\
\text { and melon (PINFA) }\end{array}$ & & & & & & & & & & & & No \\
\hline $\begin{array}{l}\text { Melam = 1,3,5-triazine- } \\
\text { 2,4,6-triamine-N-[4,6-di- } \\
\text { amino-1,3,5-triazine-2-y] }\end{array}$ & $\mathrm{C}_{6} \mathrm{H}_{9} \mathrm{~N}_{11}$ & $3576-88-3$ & & & & $\begin{array}{l}\text { Not classi- } \\
\quad \text { fied }\end{array}$ & & & & & & + \\
\hline $\begin{array}{l}\text { Melon = 1,3,5-Tri- } \\
\text { azine-2,4,6-triamine, } \\
\text { deammoniated (PINFA) }\end{array}$ & $\begin{array}{c}\left(\mathrm{C}_{6} \mathrm{H}_{3} \mathrm{~N}_{9}\right) 1- \\
3 \mathrm{H}_{3} \mathrm{~N}\end{array}$ & $\begin{array}{c}68649- \\
66-1\end{array}$ & & & $\begin{array}{l}\text { Not classi- } \\
\quad \text { fied }\end{array}$ & & & & & & & + \\
\hline
\end{tabular}

H361 = Reprotoxic 2; H373 = Single target organ toxicity, Respiratory 2. BP = brief profile (summary report) in the ECHA site

TABLE 6: The chemical properties of the mineral flame retardants of the Plastic Additives Initiative (in red: the functional concentration is higher than the concentration that makes a waste hazardous).

\begin{tabular}{|c|c|c|c|c|c|c|c|c|c|c|c|c|c|}
\hline Elements & Name & Formula & CAS & FC\% & $\begin{array}{l}\text { Polymer } \\
\text { type }\end{array}$ & $\begin{array}{l}\text { Self-clas- } \\
\text { sification }\end{array}$ & & & & & & ECHA & BP \\
\hline $\mathrm{Sb}$ & $\begin{array}{l}\text { Diantimony } \\
\text { trioxide }\end{array}$ & $\mathrm{Sb}_{2} \mathrm{O}_{3}$ & $\begin{array}{l}1309- \\
64-4\end{array}$ & 8 & $\begin{array}{l}\text { Polyolefin-I; } \\
\text { Polyolefin-II; } \\
\text { PVC (soft); } \\
\text { ABS; PA }\end{array}$ & H351 1\% & H373 & $\begin{array}{l}\mathrm{H} 411 \\
2.5 \%\end{array}$ & $\mathrm{H} 412$ & H372 & H360 & $\begin{array}{c}\mathrm{H} 351 \\
1 \%\end{array}$ & + \\
\hline$B, P$ & $\begin{array}{l}\text { Boron } \\
\text { orthophos- } \\
\text { phate }\end{array}$ & $\mathrm{BO}_{4} \mathrm{P}$ & $\begin{array}{c}13308- \\
51-5\end{array}$ & n.a. & n.a. & H319 20\% & $\begin{array}{l}\mathrm{H} 315 \\
20 \%\end{array}$ & H335 & $\mathrm{H} 360$ & $\mathrm{H} 302$ & & & + \\
\hline $\mathrm{B}, \mathrm{Zn}$ & $\begin{array}{l}\text { Hexaboron } \\
\text { dizinc un- } \\
\text { decaoxide }\end{array}$ & $\mathrm{B}_{6} \mathrm{O}_{11} \mathrm{Zn}_{2}$ & $\begin{array}{c}12767- \\
90-7\end{array}$ & $\begin{array}{c}0.3- \\
0.4\end{array}$ & $\begin{array}{l}\text { Polyolefin-I; } \\
\text { Polyolefin-II; } \\
\text { PA }\end{array}$ & $\mathrm{H} 400$ & $\begin{array}{c}\text { H319 } \\
20 \%\end{array}$ & H361 & $\begin{array}{l}\mathrm{H} 411 \\
2.5 \%\end{array}$ & $\begin{array}{l}\mathrm{H} 410 \\
0.25 \%\end{array}$ & H335 & & + \\
\hline $\mathrm{Al}$ & $\begin{array}{l}\text { Aluminium } \\
\text { hydroxide }\end{array}$ & $\mathrm{AlH}_{3} \mathrm{O}_{3}$ & $\begin{array}{c}21645- \\
51-2\end{array}$ & $\begin{array}{l}0.25- \\
50.0\end{array}$ & $\begin{array}{l}\text { Polyolefin-l; } \\
\text { PUR; PA }\end{array}$ & NC & $\begin{array}{c}\mathrm{H} 319 \\
20 \%\end{array}$ & H335 & $\begin{array}{c}\text { H315 } \\
\text { Skin irrit. } \\
220 \%\end{array}$ & & & & + \\
\hline $\mathrm{Al}$ & $\begin{array}{l}\text { Boehmite } \\
(\mathrm{Al}(\mathrm{OH}) \mathrm{O})\end{array}$ & $\mathrm{AlHO}_{2}$ & $\begin{array}{c}1318- \\
23-6\end{array}$ & 5 & PA & NC & & & & & & & + \\
\hline $\mathrm{Al}, \mathrm{Na}$ & $\begin{array}{l}\text { Aluminium } \\
\text { sodium } \\
\text { dioxide }\end{array}$ & $\mathrm{AlO}_{2} \cdot \mathrm{Na}$ & $\begin{array}{c}1302- \\
42-7\end{array}$ & n.a. & n.a. & H318 10\% & $\begin{array}{l}\text { H314 } \\
1 \mathrm{~A} 1 \%\end{array}$ & $\begin{array}{c}\mathrm{H} 314 \\
1 \mathrm{~B}\end{array}$ & $\mathrm{H} 271$ & & & & + \\
\hline $\mathrm{Al}, \mathrm{Na}$ & $\begin{array}{l}\text { Aluminium } \\
\text { sodium } \\
\text { tetrahy- } \\
\text { droxide }\end{array}$ & $\mathrm{AlH}_{4} \mathrm{NaO}_{4}$ & $\begin{array}{c}12251- \\
53-5\end{array}$ & n.a. & n.a. & H314 & $\begin{array}{c}\mathrm{H} 318 \\
10 \%\end{array}$ & & & & & & + \\
\hline $\mathrm{Mg}$ & $\begin{array}{l}\text { Magnesium } \\
\text { hydroxide }\end{array}$ & $\mathrm{MgH}_{2} \mathrm{O}_{2}$ & $\begin{array}{c}1309- \\
42-8\end{array}$ & $\begin{array}{l}4.0- \\
8.0\end{array}$ & $\begin{array}{l}\text { Polyolefin-I; } \\
\text { Polyolefin-II; } \\
\text { ABS }\end{array}$ & NC & $\begin{array}{c}\mathrm{H} 319 \\
20 \%\end{array}$ & $\begin{array}{l}\mathrm{H} 315 \\
20 \%\end{array}$ & H335 & & & & + \\
\hline $\mathrm{Ca}$ & $\begin{array}{l}\text { Calcium } \\
\text { dihydroxide }\end{array}$ & $\mathrm{CaH}_{2} \mathrm{O}_{2}$ & $\begin{array}{c}1305- \\
62-0\end{array}$ & n.a. & n.a. & H318 10\% & $\begin{array}{c}\mathrm{H} 315 \\
20 \%\end{array}$ & H335 & & & & & + \\
\hline $\mathrm{Ca}, \mathrm{Mg}$ & $\begin{array}{l}\text { Calcium } \\
\text { mag- } \\
\text { nesium } \\
\text { dihydroxide } \\
\text { oxide }\end{array}$ & $\begin{array}{l}\mathrm{CaH}- \\
{ }_{2} \mathrm{MgO}_{3}\end{array}$ & $\begin{array}{c}58398- \\
71-3\end{array}$ & n.a. & n.a. & H318 10\% & $\begin{array}{c}\mathrm{H} 315 \\
20 \%\end{array}$ & H335 & & & & & + \\
\hline
\end{tabular}

H351 = Carcinogenic 2. $B P=$ brief profile (summary report) in the ECHA site

https://polystyreneloop.eu/). POP substances present in plastics must in all cases be destroyed or irreversibly modified. The most common method today is the incineration in an industrial waste incinerator, or in small proportions in a municipal solid waste incinerator or in cement kilns, with quality control of the fumes and the ashes.

The proposal of the bromine industry (Haarman et al. 2020) recommending moving the plastic sorting limit from 
TABLE 7: Synthesis of the chemical properties of the flame retardants of the Plastic Additives Initiative and the Producer's catalog.

\begin{tabular}{|c|c|c|c|c|}
\hline $\begin{array}{l}\text { Flame } \\
\text { retardants }\end{array}$ & Data & $\mathbf{n}$ & $\begin{array}{l}\mathrm{n} \text { with functional concentra- } \\
\text { tion }>\text { hazardous concentra- } \\
\text { tion (Minimal } \mathrm{n} \text { ) }\end{array}$ & $\begin{array}{l}n \text { under assessment by } \\
\text { ECHA }\end{array}$ \\
\hline \multirow[t]{3}{*}{$\mathrm{Br}$} & Plastic Additive Initiative (PAI) & 7 & 1 & 7 \\
\hline & $\begin{array}{l}\text { Among which: Plastic Additive Initiati-e - other } \\
\text { than produ'er's catalogs }\end{array}$ & 3 & 1 & 3 \\
\hline & 3 main Producer's catalogs (Hennebert 2021) & 34 & 3 & 5 \\
\hline $\mathrm{P}$ and $\mathrm{P}-\mathrm{Cl}$ & PAI (12) + PINFA (2) & 14 & 4 & 3 \\
\hline $\mathrm{Cl}$ & PAl & 3 & $1(\mathrm{ECHA})$ & 2 \\
\hline $\mathrm{N}$ & PAI (3) + PINFA (2) & 5 & 2 & 0 \\
\hline $\mathrm{Sb}$ & PAl & 1 & 1 & 0 \\
\hline $\mathrm{B}(\mathrm{P}, \mathrm{Zn}), \mathrm{Al}(\mathrm{Na}), \mathrm{Mg}, \mathrm{Ca}$ & PAl & 9 & 0 & 0 \\
\hline Total (PAI only) & & 35 & $9(26 \%$ of 35$)$ & $12(34 \%$ of 35$)$ \\
\hline $\begin{array}{l}\text { Total (PAI + Produ'er's } \\
\text { Catalogs) }\end{array}$ & & 69 & $12(17 \%$ of 69$)$ & $13(19 \%$ of 69$)$ \\
\hline
\end{tabular}

$2000 \mathrm{mg} \mathrm{Br} / \mathrm{kg}$ total (EN 50625-3-1) to $6000 \mathrm{mg} \mathrm{Br} / \mathrm{kg}$, since regulated BFRs are no longer used, is not valid, since all substitutes are being reassessed by the ECHA as persistent, bioaccumulative and toxic (PBT), endocrine disrupting (ED) or both (Table 2). This results from very incomplete classification files: the toxicity and ecotoxicity data for humans are simply entered as not available ... A great advantage of this $2000 \mathrm{mg}$ of total bromine $\mathrm{kg}$ of plastic is that it includes all substitutive brominated substances. It is not too conservative because all these substitutes (with the exception of additive and polymers) are currently re-evaluated by ECHA and may be prohibited at the protective fire concentration in recycled plastics.

\section{CONCLUSIONS}

This study is focused on flame retardants only. Many ECHA dossiers for the registration of substances are uncompleted. Twelve flame retardants with $\mathrm{Br}, \mathrm{P}, \mathrm{Cl}, \mathrm{N}$ and $\mathrm{Sb}$ are used in concentration that makes the plastic hazardous when it becomes a waste. This could hamper the acceptance of these plastics when recycled in the circular

\section{$\mathrm{Br}$ in CRT plastic scraps $(\mathrm{n}=\mathbf{3 5 0})$}

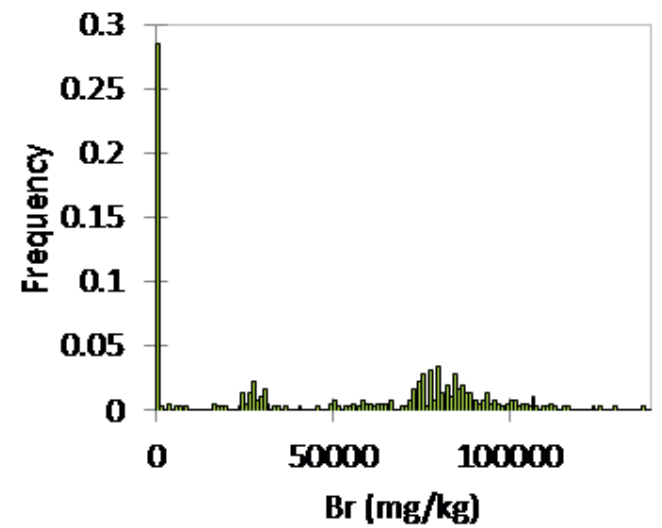

economy. Thirteen flame retardants with $\mathrm{Br}, \mathrm{P}$ and $\mathrm{Cl}$ are reassessed by the ECHA as PBT (persistent, bioaccumulative, toxic), ED (endocrine disruptor), PBT + ED, or Ss (skin sensitising). These 13 substances must not become future "legacy" substances, hindering or prohibiting the recycling of these plastics.

Density sorting is effective, but dense polymers without FR or with harmless additives are lost. A second sorting step is necessary to sort these plastics into the dense fraction. Financial incentives and the participation of the producers are now necessary to promote this second sorting stage.

The technical concentration limit of $2000 \mathrm{mg}$ total $\mathrm{Br}$ / $\mathrm{kg}$ for sorting includes all organobromine substances and is not too conservative since these substances are all currently reassessed by the ECHA.

\section{ACKNOWLED GMENTS}

This work has been supported by Ineris and by the Ministry for Ecologic Transition, France.

\section{$\mathrm{Br}$ in CRT plastic scaps $(\mathrm{n}=\mathbf{3 5 0})$}

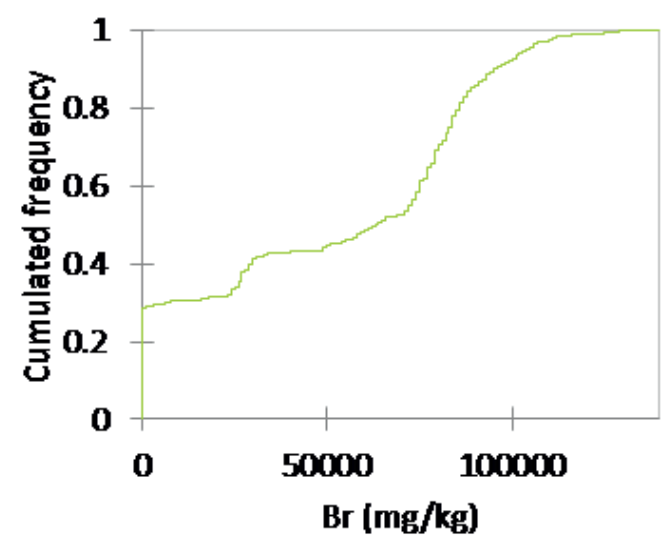

FIGURE 4: Distribution of total bromine in the dense fraction of plastic scraps of screens, mainly cathode ray tubes (CRT) (Hennebert 2019b). 


\section{REFERENCES}

AFP 2015. EPA identifies safer substitute flame retardants for consumer and commercial products, Additives for Polymers, Volume 2015, Issue 1, 2015, Page 11, ISSN 0306-3747, https://doi. org/10.1016/S0306-3747(15)70015-1.

Alaee, M., Arias, P., Sjodin, A., Bergman, A. (2003). An overview of commercially used brominated flame retardants, their applications, their use patterns in different countries/regions and possible modes of release. Environ. Int. 29, 683-689.

Bonifazi G, Fiore L, Gasbarrone R, Hennebert P, Serranti S. 2021. Detection of brominated plastics from e-waste by short wave infrared spectroscopy.Recycling 2021, 6, 54. https://doi.org/10.3390/ recycling6030054

Chen M-J, Wang X, Tao M-C, Liu X-Y, Liu Z-G, Zhang Y, Zhao C-S, Wang J-S. 2018. Full substitution of petroleum-based polyols by phosphorus-containing soy-based polyols for fabricating highly flameretardant polyisocyanurate foams, Polymer Degradation and Stability, Volume 154, 2018, Pages 312-322, ISSN 0141-3910, https:// doi.org/10.1016/j.polymdegradstab.2018.07.001.

Chen S.J., Ma Y.J., Wang J., Tian M., Luo X.J., Chen D., Mai B.X. (2010) Measurement and human exposure assessment of brominated flame retardants in household products from South China. Journal of Hazardous Materials, 176, 979-984. doi:10.1016/j. jhazmat.2009.11.138

Cui M, Li J, Chen X, Hong W, Chen Y, Xiang J, Yan J, Fan H. 2021. A halogen-free, flame retardant, waterborne polyurethane coating based on the synergistic effect of phosphorus and silicon, Progress in Organic Coatings, Volume 158, 2021, 106359, ISSN 0300-9440, https://doi.org/10.1016/j.porgcoat.2021.106359.

Delaporte N, Perea A, Paolella A, Dubé J, Vigeant M-J, Demers H, Clément D, Zhu W, Gariépy V, Zaghib K. 2021. Alumina-flame retardant separators toward safe high voltage Li-lon batteries, Journal of Power Sources, Volume 506, 2021, 230189, ISSN 0378-7753, https://doi.org/10.1016/j.jpowsour.2021.230189.

Drage, D.S., Sharkey, M., Abdallah, M.A.E., Berresheim, H., Harrad, S., 2018. Brominated flame retardants in Irish waste polymers: Concentrations, legislative compliance, and treatment options. Sci. Total Environ. 625, 1535-1543. https://doi.org/10.1016/j.scitotenv. 2018.01.076

ECHA 2021a. Plastics additives initiative. Accessed 08/2021. https:// echa.europa.eu/fr/plastic-additives-initiative

ECHA 2021b. Information on chemicals. Accessed 08/2021. https:// echa.europa.eu/information-on-chemicals

EN 50625-3-1 :2015 Requirements for the collection, logistics and treatment of WEE-E - Part 3-1 : Specification relating to depollutio-n - General. CENELEC, Brussels, Belgium.

EU 2014. Commission Decision 2014/955/EU of 18 December 2014 amending Decision 2000/532/EC on the list of waste pursuant to Directive 2008/98/EC of the European Parliament and of the Council. https://eur-lex.europa.eu/legal-content/EN/TXT/PDF /?uri=CELEX:32014D0955\&qid $=1628498956448 \&$ from $=$ ENht tp ://eurlex.europa.eu/legalcontent/EN/TXT/PDF/?uri=CELEX 32014D0955\&rid=1

EU 2016. Regulation (EC) No 850/2004 of the European parliament and of the Council of 29 April 2004 on persistent organic pollutants (POP) and amending Directive 79/117/EEC. Official Journal of the European Union, L 158, p. 7, 30.4.2004, last amended Commission Regulation (EU) 2016/460 of 30 March 2016, Official Journal of the European Union, L 80, p. 17, 31.3.2016. https://eur-lex.europa.eu/ legal-content/EN/TXT/PDF/?uri=CELEX:32004R0850\&qid=16284 99041445\&from $=\mathrm{EN}$

EU 2017. Council Regulation (EU) 2017/997 of 8 June 2017 amending Annex III to Directive 2008/98/EC of the European Parliament and of the Council as regards the hazardous property HP 14 'Ecotoxic'. Official Journal of the European Union. 14.6.2017. L 150/1. https:// eur-lex.europa.eu/legal-content/EN/TXT/PDF/?uri=CELEX:32017 R0997\&qid=1628499011457\&from $=E N$
EU 2019. Regulation (EU) 2019/1021 of the European parliament and of the Council of 20 June 2019 on persistent organic pollutants. Official Journal of the European Union, L 169, p. 45-77, 25.06.2019. https://eur-lex.europa.eu/legal-content/EN/TXT/PDF/?uri=CELEX: 32019R1021\&qid $=1628498569794 \&$ from $=E N$

Gibertini E, Carosio F, Aykanat K, Accogli A, Panzeri G, Magagnin L. 2021. Silica-encapsulated red phosphorus for flame retardant treatment on textile, Surfaces and Interfaces, Volume 25, 2021, 101252, ISSN 2468-0230, https://doi.org/10.1016/j.surfin.2021.101252.

Haarman A, Magalini F, Courtois J. 2020. SOFIES. Study on the Impacts of Brominated Flame Retardants on the Recycling of WEEE plastics in Europe. SOFIES for BSEF. $44 \mathrm{p}$.

Hennebert P, Beggio G. 2021. Sampling and sub-sampling of granular waste: Size of a representative sample in terms of number of particles and application to waste containing rare particles in concentration. Detritus. DOI: 10.31025/2611-4135/2021.15139

Hennebert P. 2019a. Hazard classification of waste: review of available practical methods and tools. Detritus. 07, 13-28. https://doi. org/10.31025/2611-4135/2019.13846

Hennebert P. 2019b. Sorting of waste for circular economy: sampling when (very) few particles have (very) high concentrations of contaminant or valuable element (with bi- or multi-modal distribution). Proceedings of the ${ }^{17}$ th International Waste Management and Landfill Symposium (Sardinia 2019), 30/09 - 04/10/2019, Cagliari, Italy

Hennebert P. 2020. Concentrations of brominated flame retardants in plastics of electrical and electronic equipment, vehicles, construction, textiles and non-food packaging: a review of occurrence and management. Detritus, Volume 12, September 2020. DO 10.31025/2611-4135/2020.13997 https://digital.detritusjournal. com/issue/volume-1-2--september-2020/363

Hennebert P. 2021. The substitution of regulated brominated flame retardants in plastic products and waste and the declared properties of the substitutes in REACh. Detritus 16 - 2021, 16-25. https://doi. org/10.31025/2611-4135/2021.15122

Huo S, Song P, Yu B, Ran S, ChevaliV S, Liu L, Fang Z, Wang H. 2021. Phosphorus-containing flame retardant epoxy thermosets: Recent advances and future perspectives, Progress in Polymer Science, Volume 114, 2021, 101366, ISSN 0079-6700, https://doi. org/10.1016/j.progpolymsci.2021.101366.

Liao Y, Chen Y, Wan C, Zhang G, Zhang F. 2021. An eco-friendly NP flame retardant for durable flame-retardant treatment of cotton fabric, International Journal of Biological Macromolecules, Volume 187 2021, Pages 251-261, ISSN 0141-8130, https://doi.org/10.1016/j. ijbiomac.2021.07.130.

PINFA 2021a. https://www.pinfa.eu/about-pinfa/who-is-pinfa/

PINFA 2021b. https://www.pinfa.eu/flame-retardants/what-are-pinfrs/

PlasticsEurope 2018. Plastics - the Facts 201-8 - An analysis of European plastics production, demand and waste data. $60 \mathrm{p}$. https:// issuu.com/plasticseuropeebook/docs/plastics_the_facts_2018-_ afweb

Santillo D, Johnston P. 2003. Playing with fire: the global threat presented by brominated flame retardants justifies urgent substitution, Environment International, Volume 29, Issue 6, 2003, Pages 725-734, ISSN 0160-4120, https://doi.org/10.1016/S01604120(03)00115-6.

Tange L, van Houwelingen J.A., Hofland W, Salemis P. 2012. Recycling of plastics with flame retardants of electronic waste, a technical and environmental challenge for a sustainable solution. Conference Electronics Goes Green (EGG) 2012.

Zhang S, Chu F, Xu Z, Zhou Y, Hu W, Hu Y. 2021. Interfacial flame retardant unsaturated polyester composites with simultaneously improved fire safety and mechanical properties, Chemical Engineering Journal, Volume 426, 2021, 131313, ISSN 1385-8947, https:// doi.org/10.1016/j.cej.2021.131313.

Zhao W, Kundu C K, Li Z, Li X, Zhang Z.2021. Flame retardant treatments for polypropylene: Strategies and recent advances, Composites Part A: Applied Science and Manufacturing, Volume 145 2021, 106382, ISSN 1359-835X, https://doi.org/10.1016/j.compositesa.2021.106382. 